\title{
Chemopreventive Potential of Select Herbal Teas and Spices on Azoxymethane-Induced Aberrant Crypt Foci in Fisher 344 Male Rats
}

\author{
Shantrell Willis, Rajitha Sunkara, Zaquavis Willis, Lillian Smith, Fredreana Hester, \\ Hadyn Matthew Reid, Priyanka Patel, Meijah McCollum, Louis Shackelford, \\ Ebube Onwasigwe, Lloyd T. Walker, Martha Verghese* \\ Department of Food and Animal Sciences, Alabama Agricultural and Mechanical University, Huntsville, USA \\ Email: *martha.verghese@aamu.edu
}

How to cite this paper: Willis, S., Sunkara, R., Willis, Z., Smith, L., Hester, F., Reid, H.M., Patel, P., McCollum, M., Shackelford, L., Onwasigwe, E., Walker, L.T. and Verghese, M. (2017) Chemopreventive Potential of Select Herbal Teas and Spices on Azoxymethane-Induced Aberrant Crypt Foci in Fisher 344 Male Rats. Food and Nutrition Sciences, 8, 348-366.

https://doi.org/10.4236/fns.2017.83024

Received: January 22, 2017

Accepted: March 27, 2017

Published: March 30, 2017

Copyright $\odot 2017$ by authors and Scientific Research Publishing Inc. This work is licensed under the Creative Commons Attribution International License (CC BY 4.0).

http://creativecommons.org/licenses/by/4.0/ (c) (i) Open Access

\begin{abstract}
Colon cancer is the third leading cause of death in the US. Selected herbal teas and spices may reduce incidence of chronic diseases, including cancer. The objective of this study was to identify the effect of strawberry leaf, raspberry leaf, hibiscus teas and cinnamon on azoxymethane (AOM)-induced aberrant crypt foci (ACF) in Fisher 344 male rats. After acclimatization period (1 wk), 49 male weanling rats were divided into 16 groups. Control (CON) group fed AIN-93G diet; 15 treatment groups were administered control diet + strawberry leaf tea (STW), raspberry leaf tea (RAS), hibiscus tea (HIB), cinnamon (CIN), strawberry leaf tea + cinnamon (STW + CIN), raspberry leaf tea + cinnamon, (RAS + CIN), hibiscus tea + cinnamon $(\mathrm{HIB}+\mathrm{CIN})$, and strawberry leaf tea + raspberry leaf tea + hibiscus tea + cinnamon in combination $(\mathrm{COM})$ at 2 levels each (teas added at $1 \%$ and $2 \%$; CIN added at $2.5 \%$ and $5 \%$ ). Rats received $24 \mathrm{mg} / \mathrm{kg}$ body weight AOM in saline s/c at 7 and 8 weeks of age. Animals received experimental diets until sacrificed by $\mathrm{CO}_{2}$ asphyxiation (17 weeks of age). ACF were enumerated in colons. Hepatic antioxidant enzymes were determined; superoxide dismutase (SOD), catalase (CAT), glutathione peroxidase (GPX), and glutathione (GH). Treatment groups had reduction in ACF compared to CON (154). Lowest ACF observed in HIB 2\% + CIN 5\% (13.16) with $91.45 \%$ reduction compared to CON. ACF observed in treatment groups administered teas and cinnamon combinations were lower than those administered teas singly. SOD and CAT activities in rats administered treatment diets were higher than CON $\left(13.63 \mathrm{U} / \mathrm{mL}, 0.95 \mathrm{umol} \cdot \mathrm{min}^{-1} \cdot \mathrm{ml}^{-1}\right)$. Rats administered COM $(20.65 \mathrm{U} / \mathrm{mL})$ had highest SOD activity. CAT activity was $51.27 \%$ higher in rats administered HIB $2 \%\left(1.96 \mathrm{umol} \cdot \mathrm{min}^{-1} \cdot \mathrm{ml}^{-1}\right.$ ). GPX activity ranged from 7.26 (STW $1 \%+$ CIN 2.5\%) to 9.59 (STW 2\%) umol. $\mathrm{min}^{-1} \cdot \mathrm{ml}^{-1}$. Results suggest that herbal teas and spices may reduce the risk of colon cancer and improve antioxidant status; regular consumption
\end{abstract}


may provide beneficial health effects.

\section{Keywords}

Herbal Tea, Antioxidant, Colon Cancer, Azoxymethane

\section{Introduction}

Cancer is an ever-growing concern in America today. According to the American Cancer Society [1] cancer, specifically colon cancer is one of the leading causes of death amongst men and women in the US. Though detection methods have improved and mortality rates decreased, there is still an urgent need for more preventive methods of cancer. Research suggests that phytochemicals in herbal substances may reduce the risk of or prevent cancer. Though detection methods have improved and decreased mortality rates, there is still an urgent need for more preventive methods of cancer. Research suggests that phytochemicals in herbal substances may reduce the risk of or prevent cancer. Accounting for these potential benefits is a diverse array of compounds with numerous biological properties.

Chemoprevention describes methods that "reverse or retard tumorigenesis" [2] [3]. Though their chemical and structural nature vary, phytochemicals may act as chemopreventing agents by inducing apoptosis, inhibiting phase I enzyme activity, reducing proliferation and inducing differentiation of cells, and increasing expression of anti-cancer genes [4] [5].

Aside from Camellia sinensis, herbal teas or infusions such as blueberry and bitter melon leaf teas (also known as leafy herbal teas, LHT) are consumed by millions due to their purported health benefits which include reductions in cardiovascular diseases (CVD), diabetes, and cancer [6]. Tea blends are also highly sought after due to their purported health benefits. Some tea blends that are common in the US consist of raspberry leaf, strawberry leaf, and hibiscus leaf teas. Tea blends are also often infused with spices for improved taste and increased positive effects on health, included the prevention of some chronic diseases such as cancer.

Raspberry leaf tea is derived from the leaves of the raspberry plant, Rubus idaeus and other species of the plant. Also known as the "American Red Raspberry" raspberries are native to Europe and North Asia. Studies conducted have suggested the health benefits of raspberry leaves including, but not limited to anti-inflammatory, antiseptic, antidiarrheic, and gastrointestinal relief [7].

Strawberry leaf tea is derived from the leaves of the plant Fragaria vesca, also known as the wild strawberry and woodland strawberry. There have been numerous health benefits of strawberry fruit, including increased serum antioxidant capacity [8], and anti-thrombotic effects [9].

Hibiscus tea is derived from the leaves of the plant Hibiscus sabdariffa. Also known as sorrel, bissap, or sour tea, hibiscus is one of the more common herbal 
teas incorporated into tea blends in the US [10]. A number of research efforts suggest many health promoting properties of hibiscus including antihypertensive [10], hypocholesterolemic [11], antimicrobial and anticancer [12] effects.

Cinnamon is a well-known spice that had been used widely as both flavoring and medicinal agents for centuries. Though multiple parts of the plant derived from the Cinnamomum genus are used, the bark is most commonly utilized. From the family Lauraceae, the Cinnamomum genus is comprised of approximately 250 species [13], with some common species C. burmanni, C. cassia, and $C$. tamala. Some health benefits of cinnamon include antioxidant and antimicrobial [14], and anti-inflammatory proterties [15].

Aberrant Crypt Foci (ACF) are commonly used as biomarkers of colon cancer [16]. The enumeration of ACF has a direct correlation with colon cancer; the greater amount of ACF that are found, the greater chances that colon cancer will develop [17]. An azoxymethane solution was used to induce colon cancer, further producing ACF.

The endogenous oxidation process may promote the pathogenesis of several chronic disease such as cancer, cardiovascular disease, diabetes, and obesity by the production of reactive oxygen species (ROS) and reactive nitrogen species (RNS) [18]. Production of ROS and RNS causes an accumulation of free radicals and induction of oxidative stress. Oxidative stress occurs when the level of prooxidants is higher than that of antioxidants. Therefore, induction of antioxidants and detoxification enzymes help combat oxidation via various mechanisms, including neutralization, scavenging, and reduction of free radicals; leading to a reduction in disease risk.

Glutathione-S Transferases (GSTs) and Catalase (CAT) are known as oxidative stress related enzymes. GSTs refer to a group of substances that serve as phase II isozymes and are a crucial part of the phase II detoxification system [19], while CAT acts in reducing DNA damage on cells, which in turn reduces the number of cells being initiated.

The objective of this study was to identify the effect of strawberry leaf, raspberry leaf, hibiscus teas and cinnamon on azoxymethane (AOM)-induced aberrant crypt foci (ACF) in Fisher 344 male rats.

\section{Materials and Methods}

\subsection{Animal Project}

\subsubsection{Experimental Design, Animal Housing and Diets}

Forty-nine Fisher 344 male weanling rats (3 weeks of age) were obtained from Harlan, IN and housed in stainless steel wire cages. After being received, a one week acclimatization period ensued for the animals. During this period, water was available ad libidum. After acclimatization period (1 wk), 49 male weanling rats were divided into 16 groups. Control (CON) group fed AIN-93G diet; 15 treatment groups were administered control diet + strawberry leaf tea (STW), raspberry leaf tea (RAS), hibiscus tea (HIB), cinnamon (CIN), strawberry leaf tea + cinnamon (STW + CIN), raspberry leaf tea+ cinnamon, (RAS + CIN), hibiscus tea + cinnamon $(\mathrm{HIB}+\mathrm{CIN})$, and strawberry leaf tea + raspberry leaf tea + hi- 
biscus tea + cinnamon in combination (COM) at 2 levels each (teas added at $1 \%$ and $2 \%$; CIN added at $2.5 \%$ and $5 \%$ ) for a period of $13 \mathrm{wk}$. Teas and cinnamon were purchased from Monterey Bay Spice Company, Watsonville, CA. For preparation of herbal teas, $120 \mathrm{~g}$ of tea leaves were boiled in $3000 \mathrm{~mL}$ of tap water for 5 minutes. Tea was then decanted from leaves and tea was diluted with tap water to make $1 \%$ and $2 \%$ decoctions. Decoctions were stored at $40^{\circ} \mathrm{C}$ until administration to rats. Cinnamon concentrations $(2.5 \%$ and $5 \%)$ were incorporated into the AIN-93G diet, at the expense of cornstarch. The composition of the AIN-93G control and cinnamon diets is shown in Table 1. The experiments were conducted according to protocols approved by the Institutional Animal Care and Use Committee of Alabama A\&M University.

\subsubsection{Induction of Aberrant Crypt Foci by Azoxymethane (AOM) and Sample Collection}

Rats received $24 \mathrm{mg} / \mathrm{kg}$ body weight $\mathrm{AOM}$ in saline s/c at 7 and $8 \mathrm{wk}$ of age. Animals received experimental diets until sacrificed by $\mathrm{CO}_{2}$ asphyxiation (17 wk of age). The AIN-93G diet is NIH approved and provided the rats with all of the nutrients they would need for growth and survival (American Institute of Nutrition). The animals were housed three to a cage with a jar of the respective diet placed in each cage; water and tea was available ad libidum. The jar of diet in each cage and animal drinking bottle with tea was replaced as needed and the weight of the animals was taken and recorded every two weeks. Upon death, the cecum, colon, and liver were obtained from each animal caucus. The $\mathrm{pH}$ of the cecal matter was measured. The livers of each rat were stored in a $-80 \mathrm{C}$ freezer until further testing. The colons of each rat were stored in a formaldehyde solution.

\subsubsection{Enumeration of Abberant Crpyt Foci Count}

Each colon was measured and divided into 2 equal portions, indicating the

Table 1. AIN-93G diet for control and treatment groups administered cinnamon.

\begin{tabular}{cccc}
\hline Ingredients (g) & $\begin{array}{c}\text { Control } \\
\text { (AIN-93G) }\end{array}$ & Cinnamon (2.5\%) & Cinnamon (5\%) \\
\hline Cornstarch & 397.50 & 372.50 & 347.50 \\
Sucrose & 100.00 & 100.00 & 100.00 \\
Casein & 200.00 & 200.00 & 200.00 \\
Fiber & 50.00 & 50.00 & 50.00 \\
Soybean oil & 70.00 & 70.00 & 70.00 \\
Dextrose & 132.00 & 132.00 & 132.00 \\
Mineral Mix (G) & 35.00 & 35.00 & 35.00 \\
Vitamin Mix & 10.00 & 10.00 & 10.00 \\
L-Cysteine & 3.00 & 3.00 & 3.00 \\
Choline & 2.50 & 2.50 & 2.50 \\
Cinnamon & 0.00 & 25.00 & 50.00 \\
\hline
\end{tabular}

AIN-93-G = American institute of nutrition diet for growth, pregnancy and lactation, $(\mathrm{G})=$ growth, $(\mathrm{g})=$ grams. 
proximal and distal ends. The proximal and distal ends of the colon were then divided into $2 \mathrm{~cm}$ segments and stained with $0.2 \%$ methylene blue and examined under a light microscope with a magnification of 10X. ACF enumeration was performed according to Bird (1995) [20]. The abberant crypt foci (ACF) were counted and categorized by location and crypt multiplicity (foci having 1, 2, 3, 4 or 5 crypts).

\subsubsection{Preparation of Liver Homogenate}

One gram of the liver samples was homogenized in $10 \mathrm{ml}$ of ice-cold potassium phosphate buffer with EDTA at a pH of 7.4 using a Potter-Elvehjem homogenizer. The homogenized livers were then centrifuged at 10,000 $\mathrm{g}$ for $15 \mathrm{mins}$. The supernatant was then centrifuged a second time at $10,000 \mathrm{~g}$ for and additional 15 mins.

\subsubsection{Determination of Hepatic Enzyme Activity}

GSTs activity of the liver was determined by measuring the conjugation of 1-chloro-2, 4-dinitrobenzene (CDNB) using methods outlined by Habig et al. (1974) [21]. The absorbance was determined at $340 \mathrm{~nm}$ for 5 mins (1 min intervals) (Biotek Synergy HT, Winooski, Vermont). Total enzyme activity was reported as $\mu \mathrm{mol} / \mathrm{mg}$.

Catalase (CAT activity was determined using a standard kit purchased from Cayman Chemicals (Ann Arbor, MI). Hydrogen peroxide $\left(\mathrm{H}_{2} \mathrm{O}_{2}\right)$ and potassium hydroxide $(\mathrm{KOH})$ was introduced to appropriate dilutions of liver homogenate and incubated with catalase potassium periodate at room temperature based on methods by Johansson and Borg (1988) [22]. Absorbance of the reaction mixture was measured at $540 \mathrm{~nm}$.

Glutathione peroxidase (GPx) activity was determined using a standard kit purchased from Cayman Chemicals (Ann Arbor, MI). Cumene $\mathrm{H}_{2} \mathrm{O}_{2}$ was introduced to liver homogenates with assay buffer to initiate the reaction mixture. Absorbance was read at $340 \mathrm{~nm}$ once every $5 \mathrm{~min}$ for $30 \mathrm{~min}$ and expressed as $\mathrm{nmol} / \mathrm{mg}$ protein based on methods by Jaskot and others [23].

For determination of Superoxide Dismutase (SOD) was determined using a standard kit purchased from Cayman Chemicals (Ann Arbor, MI) according to methods outlined by Fridovich [24].

Reduced glutathione (GSH) forms (nmol/mg protein) was measured using a spectrophotometric assay kit purchased from Cayman Chemicals (Ann Arbor, MI) (Griffith, 1985) [25].

\subsection{Statistical Analysis}

Results are presented as means \pm SEM using SAS system version 9.3. ANOVA was used to determine any significant differences among the treatment groups. Significance was determined at $\mathrm{p} \leq 0.05$. The means were separated using $\mathrm{Tu}$ key's Studentized Range Test.

\section{Results}

\subsection{General Observations, Weight Gain, Feed Intake}

Concentrations of tea and diets containing cinnamon did not produce any ob- 
servable toxicity. Table 2 shows the weight gain and feed intake of rats fed control and treatment diets. The weight gain of the control group was significantly ( $\mathrm{p} \leq 0.05$ ) higher than the treatment groups except HIB 2\%. Among the treatment groups, there were no significant $(\mathrm{p} \leq 0.05)$ differences in weight gain in rats fed herbal teas and spices with the exception of group fed teas and spice in combination $(\mathrm{COM})$, which had a significantly $(\mathrm{p} \leq 0.05)$ lower weight gain.

Rats administered the control diet had a significantly $(\mathrm{p} \leq 0.05)$ higher feed intake ( $16.77 \mathrm{~g} /$ day) compared to the treatment groups; however there were no significant differences in feed intake among the treatment groups. Feed intake of rats in the treatment groups ranged from a low of13.38 (STW 2\%) to a high of 15.14 (RAS + CIN2) g/day. Comparing the $2^{\text {nd }}$ and $3^{\text {rd }}$ columns in Table 2 , the CON group had a significantly $(\mathrm{p} \leq 0.05)$ higher feed intake and weight gain, while the COM group had the lowest feed intake and weight gain.

Table 3 shows cecal weight and $\mathrm{pH}$ of rats fed control and treatment diets. Cecal contents can serve as an indicator of gastro intestinal function. A lower cecal $\mathrm{pH}$ may suggest the presence of short-chain fatty acids, as a result of fermentation of fiber in the gut. There were no significant $(p \leq 0.05)$ differences in cecal weight and cecal $\mathrm{pH}$ among the control and treatment groups; however, rats fed cinnamon at 5\% had numerically higher cecal weight and one of the lowest cecal $\mathrm{pH}$ values. Cecal weight ranged from a low of 0.76 in COM to a high

Table 2. Weight gain and daily feed intake of rats administered herbal teas and cinnamon singly and in combination.

\begin{tabular}{ccc}
\hline Groups & Weight Gain/17wk $(\mathrm{g})$ & Feed Intake/day $(\mathrm{g})$ \\
\hline CON & $233.05 \pm 1.51^{\mathrm{a}}$ & $16.77^{\mathrm{a}}$ \\
STW 1\% & $201.00 \pm 0.57^{\mathrm{b}}$ & $13.73^{\mathrm{b}}$ \\
STW 2\% & $224.50 \pm 1.20^{\mathrm{b}}$ & $13.38^{\mathrm{b}}$ \\
RAS 1\% & $214.00 \pm 3.46^{\mathrm{b}}$ & $13.88^{\mathrm{b}}$ \\
RAS 2\% & $206.33 \pm 0.33^{\mathrm{b}}$ & $13.43^{\mathrm{b}}$ \\
HIB 1\% & $197.67 \pm 1.45^{\mathrm{b}}$ & $13.66^{\mathrm{b}}$ \\
HIB 2\% & $230.00 \pm 8.50^{\mathrm{a}}$ & $13.51^{\mathrm{b}}$ \\
CIN 2.5\% & $195.00 \pm 6.74^{\mathrm{b}}$ & $13.55^{\mathrm{b}}$ \\
CIN 5\% & $190.06 \pm 4.17^{\mathrm{b}}$ & $13.53^{\mathrm{b}}$ \\
STW + CIN1 & $193.33 \pm 7.21^{\mathrm{b}}$ & $13.62^{\mathrm{b}}$ \\
STW + CIN2 & $199.00 \pm 7.76^{\mathrm{b}}$ & $13.64^{\mathrm{b}}$ \\
RAS + CIN1 & $208.33 \pm 4.84^{\mathrm{b}}$ & $13.56^{\mathrm{b}}$ \\
RAS + CIN2 & $207.50 \pm 0.33^{\mathrm{b}}$ & $15.14^{\mathrm{b}}$ \\
HIB + CIN1 & $205.33 \pm 2.60^{\mathrm{b}}$ & $13.56^{\mathrm{b}}$ \\
HIB + CIN2 & $224.33 \pm 3.21^{\mathrm{b}}$ & $13.91^{\mathrm{b}}$ \\
COM & $175.33 \pm 0.88^{\mathrm{c}}$ & $13.52^{\mathrm{b}}$ \\
\hline
\end{tabular}

Values are \pm SEM $n=3$. ${ }^{\text {abc }}$ Mean in rows with different letters differ $(\mathrm{p} \leq 0.05)$ using Tukey's studentized range test. Abbreviations: STW = strawberry leaf tea, RAS = raspberry leaf tea, HIB = hibiscus tea, CIN = cinnamon, $\mathrm{COM}=$ combination of strawberry and raspberry leaf teas, hibiscus tea and cinnamon. 
Table 3. Cecal weight and cecal $\mathrm{pH}$ of rats administered herbal teas and cinnamon singly and in combination.

\begin{tabular}{ccc}
\hline Groups & Cecal Weight $(\mathrm{g})$ & Cecal pH \\
\hline CON & $1.07 \pm 0.08^{\mathrm{b}}$ & $6.86 \pm 0.16^{\mathrm{a}}$ \\
STW 1\% & $0.86 \pm 0.05^{\mathrm{b}}$ & $6.76 \pm 0.04^{\mathrm{a}}$ \\
STW 2\% & $1.08 \pm 0.02^{\mathrm{ab}}$ & $6.38 \pm 0.23^{\mathrm{a}}$ \\
RAS 1\% & $0.90 \pm 0.06^{\mathrm{b}}$ & $6.72 \pm 0.01^{\mathrm{a}}$ \\
RAS 2\% & $1.23 \pm 0.02^{\mathrm{ab}}$ & $7.38 \pm 0.29^{\mathrm{a}}$ \\
HIB 1\% & $0.90 \pm 0.14^{\mathrm{ab}}$ & $7.38 \pm 0.14^{\mathrm{a}}$ \\
HIB 2\% & $1.28 \pm 0.18^{\mathrm{ab}}$ & $7.30 \pm 0.08^{\mathrm{a}}$ \\
CIN 2.5\% & $1.33 \pm 0.28^{\mathrm{ab}}$ & $6.77 \pm 0.14^{\mathrm{a}}$ \\
CIN 5\% & $1.64 \pm 0.24^{\mathrm{a}}$ & $6.82 \pm 0.05^{\mathrm{a}}$ \\
STW + CIN1 & $1.11 \pm 0.16^{\mathrm{ab}}$ & $6.73 \pm 0.32^{\mathrm{a}}$ \\
STW + CIN2 & $0.89 \pm 0.04^{\mathrm{b}}$ & $7.35 \pm 0.27^{\mathrm{a}}$ \\
RAS + CIN1 & $1.01 \pm 0.10^{\mathrm{ab}}$ & $7.67 \pm 0.49^{\mathrm{a}}$ \\
RAS + CIN2 & $0.79 \pm 0.06^{\mathrm{b}}$ & $7.67 \pm 0.24^{\mathrm{a}}$ \\
HIB + CIN1 & $0.81 \pm 0.08^{\mathrm{b}}$ & $6.74 \pm 0.29^{\mathrm{a}}$ \\
HIB + CIN2 & $0.97 \pm 0.02^{\mathrm{b}}$ & $7.62 \pm 0.38^{\mathrm{a}}$ \\
COM & $0.76 \pm 0.07^{\mathrm{b}}$ & $7.53 \pm 0.26^{\mathrm{a}}$ \\
\hline
\end{tabular}

Values are \pm SEM $n=3$. abc Mean in rows with different letters differ $(\mathrm{p} \leq 0.05)$ using Tukey's studentized range test. Abbreviations: STW = strawberry leaf tea, RAS = raspberry leaf tea, HIB = hibiscus tea, CIN = cinnamon, $\mathrm{COM}=$ combination of strawberry and raspberry leaf teas, hibiscus tea and cinnamon.

or 1.64 in CIN 5\%. Cecal pH, however, ranged from a low of 6.38 in STW 2\% to a high of 7.67 in RAS + CIN1.

\subsection{Total Crypt and Crypt Multiplicity of Rats Administered Herbal Teas and Cinnamon}

Table 4 shows the number of total crypts in the colons of AOM-induced rats administered herbal teas and cinnamon. AOM is a known inducer of colon cancer; as a result of $\mathrm{AOM}$, abnormal cells (aberrant crypt foci (ACF)) are formed in the colon. ACF are used as biomarkers of colon cancer incidence. Rats fed the control diet alone had an 8-fold higher total number of crypts compared to the treatment groups. The lowest number of crypts among treatment groups was seen in rats administered cinnamon and strawberry leaf tea at $2.5 \%$ and $1 \%$ (45.33). Among groups administered strawberry leaf tea and hibiscus teas singly, STW 1\% (49) and HIB 1\% (48.33) had a lower number of total crypts compared to their $2 \%$ counterparts. In the RAS fed groups, the group administered RAS $2 \%$ (118.66) had a lower number of total crypts compared to RAS 1\% (171.33). A similar effect was observed in treatment groups administered STW + CIN, RAS + CIN, and HIB + CIN. The groups fed combination tea and cinnamon had significantly ( $\mathrm{p} \leq 0.05)$ lower number of total crypts at $2 \%$ compared to their $1 \%$ counterpart with the exception of STW + CIN. All groups fed treatment diets had reductions in total crypts compared to the control, with reductions ranging 
Table 4. Total number of crypts in colons of AOM-induced rats fed herbal teas and cinnamon.

\begin{tabular}{cc}
\hline Groups & Total Crypts \\
\hline CON & $790.00^{\mathrm{a}}$ \\
STW 1\% & $49.00^{\mathrm{h}}$ \\
STW 2\% & $136.00^{\mathrm{d}}$ \\
RAS $1 \%$ & $171.33^{\mathrm{b}}$ \\
RAS 2\% & $118.66 \mathrm{e}$ \\
HIB 1\% & $48.33^{\mathrm{h}}$ \\
HIB 2\% & $153.00^{\mathrm{c}}$ \\
CIN 2.5\% & $74.00^{\mathrm{g}}$ \\
CIN 5\% & $96.00^{\mathrm{c}}$ \\
STW + CIN1 & $45.33^{\mathrm{h}}$ \\
STW + CIN2 & $52.66^{\mathrm{h}}$ \\
RAS + CIN1 & $70.00^{\mathrm{g}}$ \\
RAS + CIN2 & $54.50^{\mathrm{h}}$ \\
HIB + CIN1 & $66.00^{\mathrm{g}}$ \\
HIB + CIN2 & $54.33^{\mathrm{h}}$ \\
COM & $60.66^{\mathrm{g}}$ \\
\hline
\end{tabular}

Values are Means, $\mathrm{n}=3 .{ }^{\text {abc }}$ Mean in rows with different letters differ $(\mathrm{p} \leq 0.05)$ using Tukey's studentized range test. Abbreviations: $\mathrm{STW}=$ strawberry leaf tea, RAS = raspberry leaf tea, $\mathrm{HIB}=$ hibiscus tea, $\mathrm{CIN}=$ cinnamon, $\mathrm{COM}=$ combination of strawberry and raspberry leaf teas, hibiscus tea and cinnamon.

from a low of $79 \%$ (RAS 1\%) to a high of $94 \%$ (STW 1\%).

Figure 1 and Figure 2 show crypt multiplicity in the colon of AOM-induced rats administered teas and cinnamon. Aberrant crypt foci (ACF) are preneoplastic lesions that serve as indicators of colon cancer incidence. If there less than 2 crypts per focus, it is likely that the cell will not become cancerous; however, if there are 3 or more crypts per focus there is a high probability that the cell will become a tumor. Crypt multiplicity is also an indicator of proliferative and inflammatory responses. Figure 1 shows crypt multiplicity in rats administered herbal teas and cinnamon singly, while Figure 2 shows crypt multiplicity in rats administered herbal teas in combination; the $\mathrm{x}$-axis represents crypt multiplicity. The control group had a significantly ( $\mathrm{p} \leq 0.05)$ higher number of ACF with 1,2, 3, 4 and 5 or more crypts per focus compared to rats fed teas and spices singly and in combination. In Figure 4.12, rats administered the control diet alone had a significantly ( $\mathrm{p} \leq 0.05)$ higher number of crypt per focus across the board. ACF with 1 crypt per focus was lowest in rats administered HIB 1\% (2). ACF with 2 and 3 crypt per focus was lowest in the group administered RAS $2 \%$ (3). ACF with 4 and 5 group per focus was lowest in rats fed HIB $1 \%$ (2.66 and 2.33).

In Figure 2, rats administered the control diet along had a significantly ( $\mathrm{p} \leq$ 0.05 ) higher number of crypts per focus. ACF with 1 crypt per focus was lowest in rats administered HIB + CIN2 (1), while ACF with 2 crypts per focus was 


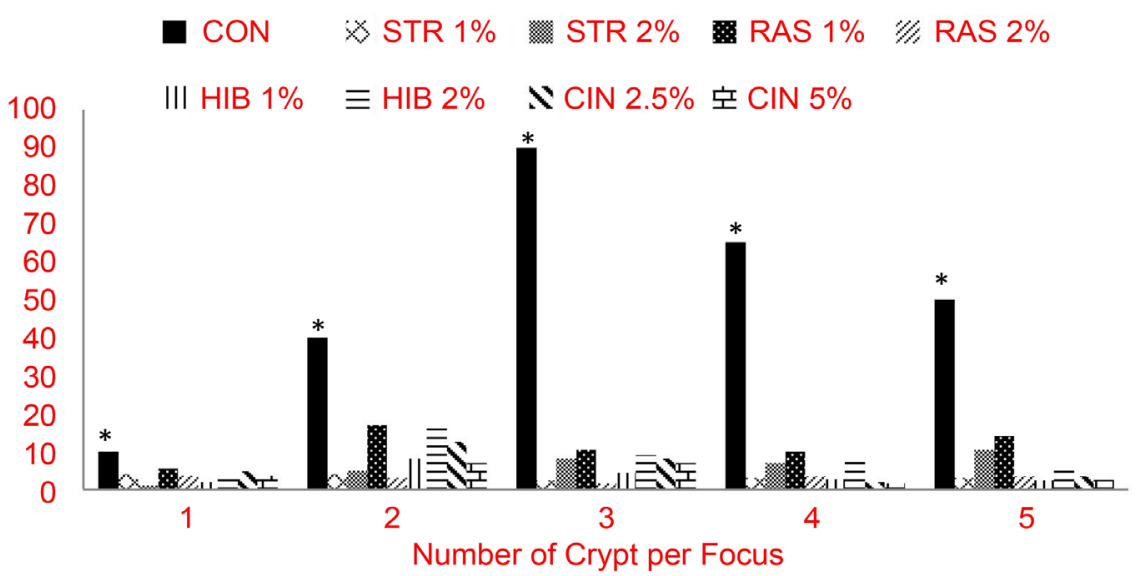

Figure 1. Crypt multiplicity in colon of AOM-induced rats fed selected teas and cinnamon singly. ${ }^{\star}$ Indicate values were significantly higher. Abbreviations: STW = strawberry leaf tea, RAS = raspberry leaf tea, HIB = hibiscus tea, CIN = cinnamon, COM = combination of strawberry and raspberry leaf teas, hibiscus tea and cinnamon.

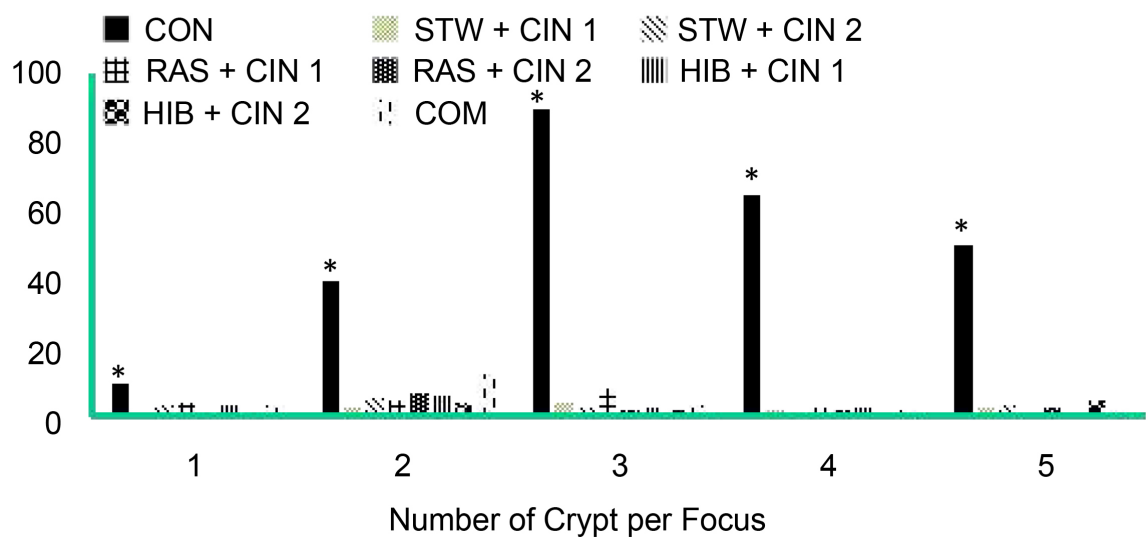

Figure 2. Crypt multiplicity in colon of AOM-induced rats fed selected teas and cinnamon in combination. ${ }^{\star}$ Indicates values were significantly higher. Abbreviations: STW = strawberry leaf tea, RAS = raspberry leaf tea, HIB = hibiscus tea, CIN = cinnamon, $\mathrm{COM}=$ combination of strawberry and raspberry leaf teas, hibiscus tea and cinnamon.

lowest in groups fed STW + CIN1 (2.66). ACF with 3 crypts per focus was lowest in rats administered RAS + CIN2 and HIB + CIN2 (2). The number of 1, 2, 3, 4 and 5 crypts per focus was lower in groups administered tea and cinnamon in combination compared to rats fed tea and cinnamon singly; suggesting a synergistic effect of herbal teas and spices.

\subsection{Hepatic Antioxidant Enzyme and Glutathione Levels}

Table 5 shows hepatic antioxidant enzymes, Superoxide Dismutase (SOD), Glutathione peroxidase (GPX) and Catalase (CAT) activities in rats fed herbal teas and cinnamon singly and in combination. SOD, GPX, and CAT, prominent in the liver, aid in regeneration of antioxidants and stabilization of free radicals. SOD catalyzes the dismutation of the superoxide radical that can cause oxidation to occur. There were significant $(\mathrm{p} \leq 0.05)$ differences between the control and treatments groups in SOD activity, with the exception of RAS $2 \%$, HIB $1 \%$ and 
Table 5. Hepatic enzyme activities in rats administered herbal teas and cinnamon singly and in combination.

\begin{tabular}{cccc}
\hline Group & SOD $(\mathrm{U} / \mathrm{g})$ & GPX $(\mathrm{mmol} / \mathrm{min} / \mathrm{g})$ & CAT $(\mathrm{mmol} / \mathrm{min} / \mathrm{g})$ \\
\hline CON & $136.30 \pm 0.68^{\mathrm{f}}$ & $14.20 \pm 0.04^{\mathrm{d}}$ & $9.50 \pm 0.01^{\mathrm{e}}$ \\
STW 1\% & $123.00 \pm 0.96 \mathrm{~g}$ & $85.00 \pm 0.68^{\mathrm{abc}}$ & $17.30 \pm 0.24^{\mathrm{c}}$ \\
STW 2\% & $160.80 \pm 0.25^{\mathrm{e}}$ & $95.59 \pm 0.15^{\mathrm{a}}$ & $14.30 \pm 0.06^{\mathrm{d}}$ \\
RAS 1\% & $163.20 \pm 0.83^{\mathrm{e}}$ & $91.40 \pm 0.28^{\mathrm{ab}}$ & $12.80 \pm 0.07^{\mathrm{d}}$ \\
RAS 2\% & $149.10 \pm 1.17^{\mathrm{f}}$ & $90.07 \pm 0.48^{\mathrm{ab}}$ & $15.10 \pm 0.17^{\mathrm{b}}$ \\
HIB 1\% & $134.70 \pm 1.21^{\mathrm{f}}$ & $76.60 \pm 0.37^{\mathrm{abc}}$ & $14.90 \pm 0.05^{\mathrm{c}}$ \\
HIB 2\% & $138.0 \pm 0.17^{\mathrm{c}}$ & $87.90 \pm 0.47^{\mathrm{abc}}$ & $19.60 \pm 0.14^{\mathrm{a}}$ \\
CIN 2.5\% & $171.81 \pm 1.25^{\mathrm{e}}$ & $90.20 \pm 0.21^{\mathrm{ab}}$ & $18.00 \pm 0.31^{\mathrm{a}}$ \\
CIN 5\% & $143.70 \pm 0.64^{\mathrm{f}}$ & $79.80 \pm 0.47^{\mathrm{abc}}$ & $11.20 \pm 0.13^{\mathrm{e}}$ \\
STW + CIN1 & $219.30 \pm 6.19^{\mathrm{c}}$ & $72.60 \pm 0.29^{\mathrm{bc}}$ & $14.10 \pm 0.24^{\mathrm{c}}$ \\
STW + CIN2 & $346.50 \pm 0.71^{\mathrm{a}}$ & $90.48 \pm 0.10^{\mathrm{ab}}$ & $16.40 \pm 0.10^{\mathrm{b}}$ \\
RAS + CIN1 & $318.50 \pm 3.51^{\mathrm{b}}$ & $90.40 \pm 0.45^{\mathrm{ab}}$ & $16.40 \pm 0.07^{\mathrm{b}}$ \\
RAS + CIN2 & $340.11 \pm 9.35^{\mathrm{a}}$ & $80.42 \pm 0.05^{\mathrm{abc}}$ & $16.60 \pm 0.09^{\mathrm{b}}$ \\
HIB + CIN1 & $195.59 \pm 1.09^{\mathrm{d}}$ & $87.00 \pm 0.49^{\mathrm{abc}}$ & $10.50 \pm 0.11^{\mathrm{e}}$ \\
HIB + CIN2 & $188.30 \pm 0.91^{\mathrm{d}}$ & $78.10 \pm 0.61^{\mathrm{c}}$ & $15.50 \pm 0.20^{\mathrm{b}}$ \\
COM & $180.40 \pm 2.48^{\mathrm{d}}$ & $81.30 \pm 0.71^{\mathrm{abc}}$ & $16.90 \pm 0.09^{\mathrm{b}}$ \\
\hline
\end{tabular}

Values are $\pm S E M, n=3 .{ }^{\text {abcd }}$ Mean on column with different letters differ $(\mathrm{p} \leq 0.05)$ using Tukey's studentized range test. Abbreviations: STW = strawberry leaf tea, RAS = raspberry leaf tea, HIB = hibiscus tea, $\mathrm{CIN}=$ cinnamon, $\mathrm{COM}=$ combination of strawberry and raspberry leaf teas, hibiscus tea and cinnamon, $\mathrm{SOD}=$ Superoxide Dismutase, $\mathrm{GPX}=$ Glutathione Peroxidase, $\mathrm{CAT}=$ Catalase .

CIN 5\%. Groups administered herbal teas and spices in combination had significantly ( $\mathrm{p} \leq 0.05$ ) higher SOD activities compared to rats fed teas and spices singly. GPX and CAT break down the hydrogen peroxide radical to molecular oxygen and water. All treatment groups ( 72.5 to $95.5 \mathrm{mmol} / \mathrm{min} / \mathrm{g}$ ) had significantly ( $\mathrm{p} \leq 0.05)$ higher GPX activity compared to the control group (14.20 $\mu \mathrm{mol} / \mathrm{min} / \mathrm{g}$ ). Administration of herbal teas and spices increased GPX activity by at least 5 -fold compared to the control. The highest GPX activity was observed in rats administered STW $2 \%(95.5 \mathrm{mmol} / \mathrm{min} / \mathrm{g})$. There were significant $(\mathrm{p} \leq$ $0.05)$ differences in CAT activity among the experimental groups. The rats administered HIB (2\%), CIN (2.5) and STW (1\%) had significantly ( $\mathrm{p} \leq 0.05)$ higher CAT activity compared to the other treatment groups. Rats administered herbal teas and cinnamon in combination (16.9), had the highest CAT activity among all treatment groups fed combination diets.

The 3 antioxidant enzymes work together to rid free radicals and are induced as needed. As SOD converts superoxide to water and hydrogen peroxide, CAT and GPX are induced in order to reduce hydrogen peroxide.

Table 6 shows glutathione levels in AOM-induced rats administered herbal teas and spices. Glutathione is a powerful antioxidant that is conjugated to xenobiotics by the action of the Phase II family of enzymes, glutathione-stransferases. Glutathione levels were found to be higher in liver of rats fed teas 
and cinnamon compared to control rats. Livers of rats administered STW 2\% and STW + CIN2 had 3- and 3.5-fold higher glutathione levels compared to the control. Among rats fed combinations diets, the highest glutathione level was observed in the STW + CIN2 (382.40) group, while the lowest glutathione level was seen in rats administered strawberry leaf tea at a $1 \%$ concentration (151.90).

In all treatment groups, glutathione levels were higher with increasing concentrations of teas and spices administered to rats. Groups administered teas and spices in combination had higher glutathione levels compared to rats fed teas and spices singly, with the exception of the RAS + CIN1 group.

Figure 3 and Figure 4 show levels of hepatic glutathione-S-transferases (GST) in rats administered herbal teas and spices singly and in combination. GSTs are a family of enzymes that catalyze conjunction of glutathione to xenobiotics. The control group had a lower GST activity compared to the treatment groups. There was an increase in GST activity with increasing concentrations of teas and spices. Among the treatment groups that were administered teas and spices singly, the group fed cinnamon at $5 \%$ (CIN $5 \%$ ) had the highest $(0.58 \mathrm{nmol} / \mathrm{min} / \mathrm{mL})$ GST activity and the group administered strawberry leaf tea at a concentration of $1 \%$ (STW 1\%) had the lowest $(0.21 \mathrm{nmol} / \mathrm{min} / \mathrm{mL})$ GST activity. As seen in Figure 4.7, the highest GST activity was seen in the group administered strawberry leaf tea at $2 \%$ in combination with CIN at 5\% (STW 2\% + CIN 5\%) $(0.62 \mathrm{nmol} /$

Table 6. Hepatic glutathione levels in rats administered herbal teas and spices.

\begin{tabular}{cc}
\hline Groups & Glutathione Levels $(\mathrm{mM} / \mathrm{g})$ \\
\hline CON & $132.59^{\mathrm{h}}$ \\
STW $1 \%$ & $151.90^{\mathrm{g}}$ \\
STW $2 \%$ & $310.10^{\mathrm{d}}$ \\
RAS $1 \%$ & $236.01^{\mathrm{e}}$ \\
RAS 2\% & $286.03^{\mathrm{f}}$ \\
HIB 1\% & $269.09^{\mathrm{a}}$ \\
HIB 2\% & $380.50^{\mathrm{f}}$ \\
CIN 2.5\% & $253.75^{\mathrm{f}}$ \\
CIN 5\% & $294.26^{\mathrm{e}}$ \\
STW + CIN1 & $300.08^{\mathrm{e}}$ \\
STW + CIN2 & $382.40^{\mathrm{a}}$ \\
RAS + CIN1 & $299.04^{\mathrm{e}}$ \\
RAS + CIN2 & $330.88^{\mathrm{c}}$ \\
HIB + CIN1 & $323.40^{\mathrm{c}}$ \\
HIB + CIN2 & $352.30^{\mathrm{b}}$ \\
COM & $289.02^{\mathrm{e}}$ \\
\hline
\end{tabular}

Values are Means, $\mathrm{n}=3$. ${ }^{\text {abcd }}$ Means with different letters differ $(\mathrm{p} \leq 0.05)$ using Tukey's studentized range test. Abbreviations: STW = strawberry leaf tea, RAS = raspberry leaf tea, HIB = hibiscus tea, CIN = cinnamon, $\mathrm{COM}=$ combination of strawberry and raspberry leaf teas, hibiscus tea and cinnamon, GSH $=$ Glutathione. 


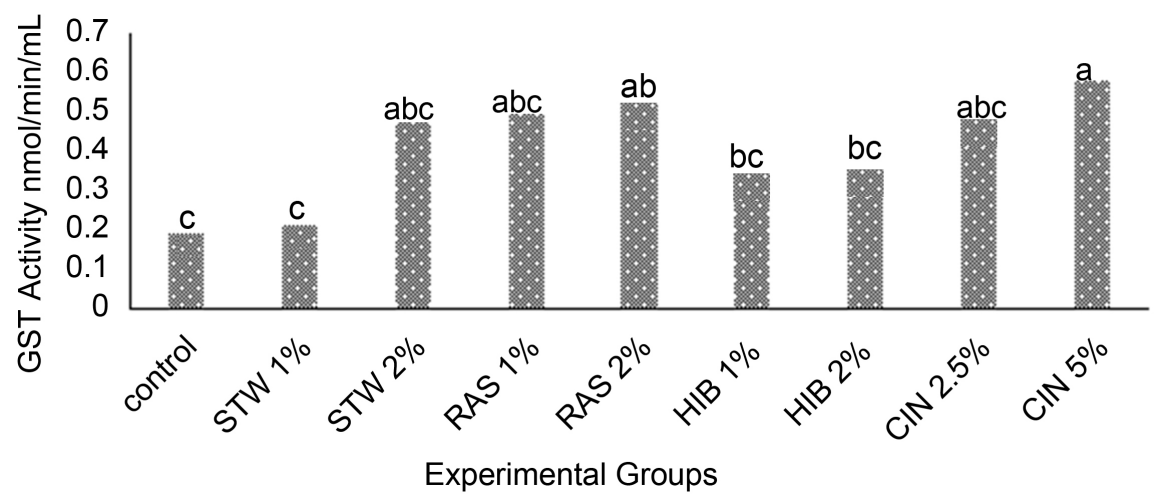

Figure 3. Hepatic glutathione-S-Transferases activity in rats fed herbal tea and cinnamon singly. Values are Means, $\mathrm{n}=3$. ${ }^{\text {abcd }}$ Mean on bars with different letters differ $(\mathrm{p} \leq 0.05)$ using Tukey's studentized range test. Abbreviations: STW = strawberry leaf tea, RAS = raspberry leaf tea, HIB = hibiscus tea, CIN = cinnamon, GST = Glutathione-S-Transferases.

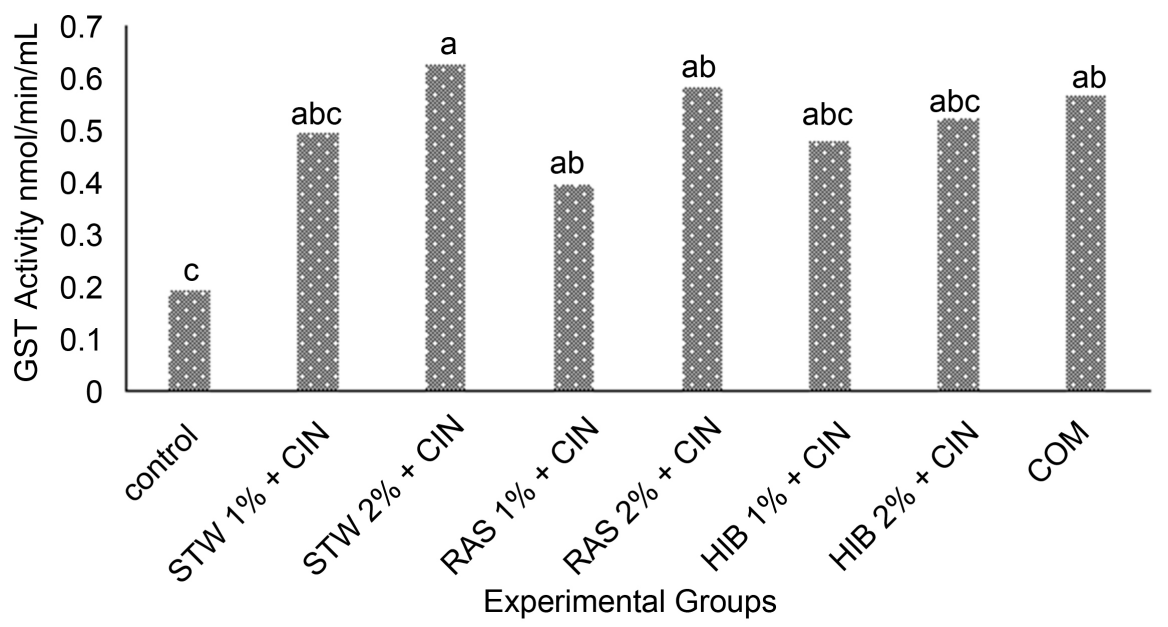

Figure 4. Hepatic glutathione-s-transferases activity in rats fed herbal teas and cinnamon in combination. Values are Means, $\mathrm{n}=3 .{ }^{\text {abcd }}$ Mean on bars with different letters differ $(\mathrm{p} \leq$ 0.05) using Tukey's studentized range test. Abbreviations: STW = strawberry leaf tea, RAS = raspberry leaf tea, $\mathrm{HIB}=$ hibiscus tea, $\mathrm{CIN}=$ cinnamon, $\mathrm{COM}=$ combination of strawberry and raspberry leaf teas, hibiscus tea and cinnamon, GST = GlutathioneS-Transferases.

min.mL) and the lowest treatment groups administered teas and spices in combination was observed in rats given raspberry leaf tea at $1 \%$ in conjunction with cinnamon at $5 \%($ RAS $1 \%+$ CIN $5 \%)(0.39 \mathrm{nmol} / \mathrm{min} / \mathrm{mL})$.

\section{Discussion}

The link between diet and disease is continually researched and it is suggested that diet plays a major role in cancer prevention [26] [27] [28]. There is strong evidence of dietary bioactive compounds, such as phytochemicals, and their role in disease prevention. Phytochemicals are secondary plant metabolites that occur within plants to provide protection to the plant [29]. A number of phytochemicals, including phenolics, carotenoids and alkaloids are derived from 
fruits, vegetables, herbs, spices, and other plant material [30] [31] [32]. Research suggests that phytochemicals in herbal substances may reduce the risk of or prevent cancer. A diverse array of compounds with numerous biological properties account for these potential benefits. Phytochemicals, including flavonoids found in tea, have proven effective against chronic diseases, including colon cancer [33].

Though research is being conducted to analyze the effect of select phytochemicals on cancer, there are a limited amount of studies that involve animal models on herbal teas and spices. The aim of the present study was to evaluate the chemopreventive potential of strawberry leaf, raspberry leaf, hibiscus teas and cinnamon.

Administration of teas and spices caused a significant decrease in weight gain and significant decrease in feed intake of rats over the $17 \mathrm{wk}$ period. Research suggests (Alarcon-Aguilar et al., 2007) the anti-obesity effect of hibiscus tea. In a study conducted by Alarcon-Aguilar and others, administration of hibiscus to MSG mice inhibited body weight gain in mice [34]. Cinnamon was shown to lower liver fat in mice administered the spice [35].

Cecal weight and cecal $\mathrm{pH}$ have been shown to be determinants of colon cancinogenesis; with dietary fiber having the ability to modulate these factors. Acidification of intestinal lumen as a result of soluble fiber consumption causes a decrease in pathogenic microorganisms, decreasing cancer risk. Though there were no significant differences in cecal $\mathrm{pH}$, the group fed $\mathrm{CIN} 5 \%$ had a numerically more acidic cecal pH compared to the control. Cinnamon contains $4.1 \mathrm{~g}$ of fiber per serving and has been linked to colon cancer reduction [36].

Carcinogenesis is a multistage process, which consists of three stages: initiation, promotion, and progression. During the initiation stage, a normal cell experiences DNA damage [37]. As this stage progresses, the initiated cell expands; where after the promotion stage is introduced. During this stage, the initiated cell affects other normal cells, and causes DNA damage, leading to preneoplastic lesions. In the final stage, progression, cancerous tumors are developed and cancer begins to spread, leading to metastasis [38]. AOM is an effective and potent inducer of carcinomas of large intestine in both male and female rats to induce aberrant crypt foci or adenomas in animal model carcinogenesis, which is why it is ideal for this study [39] [40] [41].

Total crypts, crypt multiplicity, and total ACF are indicative of oxidation, proliferation and inflammation; all of which are increased during the process of carcinogenesis. In the present student all treatment groups had lower crypts, ACF, and crypt multiplicity compared to the control group. Previous studies have shown antiproliferative, antioxidant and anti-inflammatory potential of hibiscus and cinnamon [42]-[47].

Oxidative stress occurs when the level of prooxidants is higher than that of antioxidants. Therefore, an increased amount of dietary antioxidants may combat oxidation via various mechanisms, including neutralization, scavenging, and reduction of free radicals; leading to a reduction in disease risk. Endogenous 
oxidation defense systems aid in reducing negative effects from free radicals. Enzymes within this system include SOD, GPX, and CAT. SOD rids the body of the superoxide radical to form hydrogen peroxide and water. CAT and GPX eliminates hydrogen peroxide to from water and molecular oxygen [48]. The highest SOD activity was seen in rats administered STW + CIN2. Similarly, in a previous study cinnamon and cardamom were shown to induce SOD activity in rats [49]; cinnamon extracts also increased SOD activity in carbon tetrachloride induced rats [50].

The highest CAT activity was seen in rats administered HIB 2\%. In a previous study, juice extracted from hibiscus increased CAT activity in AOM induced rats [51].

Glutathione (GSH) is an antioxidant that is conjugated to xenobiotics, ultimately increasing excretion of the xenobiotic. GST is a Phase II enzyme that conjugates GSH to xenobiotics for detoxification. In the present study, glutathione levels were increased in the treatment groups, while the highest glutathione level was observed in the STW + CIN2 group. Previous studies have shown the enhancement in activity and higher levels of GST, GSH and other antioxidants in animals administered cinnamon and leafy herbal teas; may lead to a decreased risk of chronic diseases such as cancer [52] [53]. In a study conducted by Hung et al. (2006), aqueous extracts of Du-Zhong leaves were seen to induce activities of a number of hepatic antioxidant enzymes, including GPX and GST [54].

The phase I and phase II biotransformation system is the main mechanism of detoxification of xenobiotics in the body. The phase II system prepares xenobiotics for excretion by increasing water solubility of the xenobiotic. Enzymes within the biotransformation system are induced based on need (increased toxins), or by the action of mono-functional or multi-functional inducers [55]. As the name suggests, mono-functional inducers increase the activity of phase I or phase II enzymes, while multi-functional inducers may induce both [55]. In a previous study, various herbal teas were evaluated for their effect on phase I and phase II enzymes in liver of rats. Animals administered dandelion tea had a significant increase in UDP-glucuronosyl transferase, a phase II enzyme. In that same study, the activity of some phase I enzymes was decreased by the administration of herbal teas [56]. In the present study, activities of hepatic detoxifying enzymes and antioxidants were increased, suggesting that phytochemicals present within the teas and spices may be inducers of phase II activity. These results align with results from a previous study conducted by Willis et al. (2016), where bitter melon and blueberry leafy herbal teas increased activities of GST, CAT, and SOD [57].

\section{Conclusions}

Traditional and herbal teas have been used for centuries to treat a wide range of ailments. Traditional teas are derived from the tea plant, while herbal teas are derived from other plants. Herbal teas and spices have been seen to be abundant sources of phytochemicals, with increasing popularity in the US market. Though 
there are many reports on the anti-cancer effect of traditional teas, there are few reports on the chemopreventive potential of herbal teas including strawberry leaf, raspberry leaf and hibiscus teas. In the present study the chemopreventive potential of teas and spices was evaluated in an AOM-induced rat model.

The evidence provided in this study suggests a link between increased selected herbal tea and spice consumption and reduced occurrence of ACF. With further research, it may be proven that a diet with an increased amount of selected herbal teas and spices may help to prevent colon cancer. The levels of oxidative stress related enzymes suggest beneficial effects

Our results indicate that strawberry leaf, raspberry leaf, hibiscus, and cinnamon exhibit chemopreventive potential again colon cancer in an azoxymethaneinduced animal model.

With the rise in the incidence of chronic diseases, the food industry has increased its focus on food products with health benefits. There is definitely a need for more research in the area of underutilized plant teas in the prevention of other chronic diseases.

Human clinical trials will be needed to determine this and provide public health recommendations.

\section{References}

[1] ACS (2014) Colorectal Cancer Facts \& Figures. American Cancer Society. https://www.cancer.org/content/dam/cancer-org/research/cancer-facts-and-statistic s/colorectalcancer-facts-and-figures/colorectal-cancer-facts-and-figures-2014-2016. pdf

[2] Surh, Y.J. (2003) Cancer Chemoprevention with Dietary Phytochemicals. Nature Reviews Cancer, 3, 768-780. https://doi.org/10.1038/nrc1189

[3] Wattenberg, L.W. (1985) Chemoprevention of Cancer. Cancer Research, 45, 1-8.

[4] Sun, J., Chu, Y.F., Wu, X. and Liu, R.H. (2002) Antioxidant and Antiproliferative Activities of Common Fruits. Journal of Agricultural and Food Chemistry, 50, 7449-7454. https://doi.org/10.1021/jf0207530

[5] Liu, R.H. (2004) Potential Synergy of Phytochemicals in Cancer Prevention: Mechanism of Action. The Journal of Nutrition, 134, 3479S-3485S.

[6] Oh, J., Jo, H., Cho, R., Kim, S. and Han, J. (2013) Antioxidant and Antimicrobial Activities of Various Leafy Herbal Teas. Food Control, 31, 403-409. https://doi.org/10.1016/j.foodcont.2012.10.021

[7] Kratchanova, M., Denev, P., Ciz, M., Lojek, A. and Mihailov, A. (2010) Evaluation of Antioxidant Activity of Medicinal Plants Containing Polyphenol Compounds. Comparison of Two Extraction Systems. Acta Biochimica Polonica, 57, 229-234.

[8] Carlton, P.S., Kresty, L.A., Siglin, J.C., Morse, M.A., Lu, J., Morgan, C. and Stoner, G. D. (2001) Inhibition of N-Nitrosomethylbenzylamine-Induced Tumorigenesis in the Rat Esophagus by Dietary Freeze-Dried Strawberries. Carcinogenesis, 22, 441 446.

[9] Naemura, A., Mitani, T., Ijiri, Y., Tamura, Y., Yamashita, T., Okimura, M. and Yamamoto, J. (2005) Anti-Thrombotic Effect of Strawberries. Blood Coagulation \& Fibrinolysis, 16, 501-509. https://doi.org/10.1097/01.mbc.0000184737.50594.a8

[10] McKay, D.L., Chen, C.O., Saltzman, E. and Blumberg, J.B. (2010) Hibiscus sabdariffa L. Tea (Tisane) Lowers Blood Pressure in Prehypertensive and Mildly Hyper- 
tensive Adults. The Journal of Nutrition, 140, 298-303. https://doi.org/10.3945/jn.109.115097

[11] Hirunpanich, V., Utaipat, A., Morales, N.P., Bunyapraphatsara, N., Sato, H., Herunsale, A. and Suthisisang, C. (2006) Hypocholesterolemic and Antioxidant Effects of Aqueous Extracts from the Dried Calyx of Hibiscus sabdariffa L. in Hypercholesterolemic Rats. Journal of Ethnopharmacology, 103, 252-260. https://doi.org/10.1016/j.jep.2005.08.033

[12] Olaleye, M.T. (2007) Cytotoxicity and Antibacterial Activity of Methanolic Extract of Hibiscus sabdariffa. Journal of Medicinal Plants Research, 1, 9-13.

[13] Prasad, K.N., Yang, B., Dong, X., Jiang, G., Zhang, H., Xie, H. and Jiang, Y. (2009) Flavonoid Contents and Antioxidant Activities from Cinnamomum Species. Innovative Food Science \& Emerging Technologies, 10, 627-632.

https://doi.org/10.1016/j.ifset.2009.05.009

[14] Singh, G., Maurya, S. and Catalan, C.A. (2007) A Comparison of Chemical, Antioxidant and Antimicrobial Studies of Cinnamon Leaf and Bark Volatile Oils, Oleoresins and Their Constituents. Food and Chemical Toxicology, 45, 1650-1661. https://doi.org/10.1016/j.fct.2007.02.031

[15] Rao, Y.K., Fang, S.H. and Tzeng, Y.M. (2007) Evaluation of the Anti-Inflammatory and Anti-Proliferation Tumoral Cells Activities of Antrodia camphorata, Cordyceps sinensis, and Cinnamomum osmophloeum Bark Extracts. Journal of Ethnopharmacology, 114, 78-85. https://doi.org/10.1016/j.jep.2007.07.028

[16] Corpet, D.E. and Pierre, F. (2003) Point: From Animal Models to Prevention of Colon Cancer. Systematic Review of Chemoprevention in Min Mice and Choice of the Model System. Cancer Epidemiology Biomarkers \& Prevention, 12, 391-400.

[17] Corpet, D.E. and Taché, S. (2002) Most Effective Colon Cancer Chemopreventive Agents in Rats: A Systematic Review of Aberrant Crypt Foci and Tumor Data, Ranked by Potency. Nutrition and Cancer, 43, 1-21. https://doi.org/10.1207/S15327914NC431_1

[18] Maritim, A.C., Sanders, A. and Watkins, J. (2003) Diabetes, Oxidative stress, and Antioxidants: A Review. Journal of Biochemical and Molecular Toxicology, 17, 2438. https://doi.org/10.1002/jbt.10058

[19] Sherratt, P. and Hayes, J. (2001) Glutathione S-Transferases Enzyme System that Metabolise Drugs, and Other Xenobiotics.

[20] Bird, R.P. (1995) Role of Aberrant Crypt Foci in Understanding the Pathogenesis of Colon Cancer. Cancer Letters, 93, 55-71. https://doi.org/10.1016/0304-3835(95)03788-X

[21] Habig, W.H., Pabst, M.J. and Jakoby, W.B. (1974) Glutathione S-Transferases, The First Enzymatic Step in Mercapturic Acid Formation. Journal of Biological Chemistry, 249, 7130-7139.

[22] Johansson, L.H. and Borg, L.A. (1988) A Spectrophotometric Method for Determination of Catalase Activity in Small Tissue Samples. Analytical Biochemistry, 174, 331-336. https://doi.org/10.1016/0003-2697(88)90554-4

[23] Jaskot, R.H., Charlet, E.G., Grose, E.C., Grady, M.A. and Roycroft, J.H. (1983) An Automated Analysis of Glutathione Peroxidase, S-Transferase, and Reductase Activity in Animal Tissue. Journal of Analytical Toxicology, 7, 86-88. https://doi.org/10.1093/jat/7.2.86

[24] Fridovich, I. (1989) Superoxide Dismutases. An Adaptation to a Paramagnetic Gas. The Journal of Biological Chemistry, 264, 7761-7764.

[25] Griffith, O.W. and Meister, A. (1985) Origin and Turnover of Mitochondrial Glu- 
tathione. Proceedings of the National Academy of Sciences of the United States of America, 82, 4668. https://doi.org/10.1073/pnas.82.14.4668

[26] Willett, W.C. (2000) Diet and Cancer. The Oncologist, 5, 393-404. https://doi.org/10.1634/theoncologist.5-5-393

[27] Williams, D., Verghese, M., Walker, L.T., Boateng, J., Shackelford, L. and Chawan, C.B. (2007) Flax Seed Oil and Flax Seed Meal Reduce the Formation of Aberrant Crypt Foci (ACF) in Azoxymethane-Induced Colon Cancer in Fisher 344 Male Rats. Food and Chemical Toxicology, 45, 153-159. https://doi.org/10.1016/j.fct.2006.08.014

[28] Verghese, M., Rao, D.R., Chawan, C.B., Williams, L.L. and Shackelford, L. (2002) Dietary Inulin Suppresses Azoxymethane-Induced Aberrant Crypt Foci and Colon Tumors at the Promotion Stage in Young Fisher 344 Rats. The Journal of Nutrition, 132, 2809-2813.

[29] Benzie, I.F. and Wachtel-Galor, S. (2011) Herbal Medicine: Biomolecular and Clinical Aspects. CRC Press, Boca Raton. https://doi.org/10.1201/b10787-2

[30] Larson, R.A. (1988) The Antioxidants of Higher Plants. Phytochemistry, 27, 969978. https://doi.org/10.1016/0031-9422(88)80254-1

[31] Liu, R.H. (2004) Potential Synergy of Phytochemicals in Cancer Prevention: Mechanism of Action. The Journal of Nutrition, 134, 3479S-3485S.

[32] Paur, I., Carlsen, M.H., Halvorsen, B.L. and Blomhoff, R. (2011) Antioxidants in Herbs and Spices.

[33] Li, W., He, N., Tian, L., Shi, X. and Yang, X. (2016) Inhibitory Effects of Polyphenol-Enriched Extract from Ziyang Tea against Human Breast Cancer MCF-7 Cells through Reactive Oxygen Species-Dependent Mitochondria Molecular Mechanism. Journal of Food and Drug Analysis, 24, 527-538. https://doi.org/10.1016/j.jfda.2016.01.005

[34] Alarcon-Aguilar, F.J., Zamilpa, A., Perez-Garcia, M.D., Almanza-Perez, J.C., Romero-Nuñez, E., Campos-Sepulveda, E.A. and Roman-Ramos, R. (2007) Effect of Hibiscus sabdariffa on Obesity in MSG Mice. Journal of Ethnopharmacology, 114, 66-71. https://doi.org/10.1016/j.jep.2007.07.020

[35] Sartorius, T., Peter, A., Schulz, N., Drescher, A., Bergheim, I., Machann, J. and Häring, H.U. (2014) Cinnamon Extract Improves Insulin Sensitivity in the Brain and Lowers Liver Fat in Mouse Models of Obesity. PLoS ONE, 9, e92358. https://doi.org/10.1371/journal.pone.0092358

[36] Wondrak, G.T., Villeneuve, N.F., Lamore, S.D., Bause, A.S., Jiang, T. and Zhang, D.D. (2010) The Cinnamon-Derived Dietary Factor Cinnamic Aldehyde Activates the Nrf2-Dependent Antioxidant Response in Human Epithelial Colon Cells. Molecules, 15, 3338-3355. https://doi.org/10.3390/molecules15053338

[37] Fearon, E.R. and Vogelstein, B. (1990) A Genetic Model for Colorectal Tumorigenesis. Cell, 61, 759-767. https://doi.org/10.1016/0092-8674(90)90186-I

[38] Cooper, G.M. (2000) The Cell: A Molecular Approach. 2nd Edition, Sunderland (MA): Sinauer Associates, The Development and Causes of Cancer. https://www.ncbi.nlm.nih.gov/books/NBK9963/

[39] Reddy, B.S. (2004) Studies with the Azoxymethane-Rat Preclinical Model for Assessing Colon Tumor Development and Chemoprevention. Environmental and Molecular Mutagenesis, 44, 26-35. https://doi.org/10.1002/em.20026

[40] Chen, J. and Huang, X.F. (2009) The Signal Pathways in Azoxymethane-Induced Colon Cancer and Preventive Implications. Cancer Biology \& Therapy, 8, 13131317. https://doi.org/10.4161/cbt.8.14.8983 
[41] Verghese, M., Rao, D.R., Chawan, C.B. and Shackelford, L. (2002) Dietary Inulin Suppresses Azoxymethane-Induced Preneoplastic Aberrant Crypt Foci in Mature Fisher 344 Rats. The Journal of Nutrition, 132, 2804-2808.

[42] Akim, A.M., Ling, L.C., Rahmat, A. and Zakaria, Z.A. (2011) Antioxidant and Anti-Proliferative Activities of Roselle Juice on caov-3, mcf-7, mda-mb-231 and Hela Cancer Cell Lines. African Journal of Pharmacy and Pharmacology, 5, 957-965.

[43] Tsai, P.J., McIntosh, J., Pearce, P., Camden, B. and Jordan, B.R. (2002) Anthocyanin and Antioxidant Capacity in Roselle (Hibiscus sabdariffa L.) Extract. Food Research International, 35, 351-356. https://doi.org/10.1016/S0963-9969(01)00129-6

[44] Narender, K.S., Kumar, D. and Kumar, V. (2009) Antinociceptive and Anti-Inflammatory Activity of Hibiscus tiliaceus Leaves. International Journal of Pharmacognosy and Phytochemistry, 1, 15-17.

[45] Tung, Y.T., Yen, P.L., Lin, C.Y. and Chang, S.T. (2010) Anti-Inflammatory Activities of Essential Oils and Their Constituents from Different Provenances of Indigenous Cinnamon (Cinnamomum osmophloeum) Leaves. Pharmaceutical Biology, 48, 1130-1136. https://doi.org/10.3109/13880200903527728

[46] Mathew, S. and Abraham, T.E. (2006) Studies on the Antioxidant Activities of Cinnamon (Cinnamomum verum) Bark Extracts, through Various in Vitro Models. Food Chemistry, 94, 520-528. https://doi.org/10.1016/j.foodchem.2004.11.043

[47] Khan, R., Sharma, M., Kumar, L., Husain, S.A. and Sharma, A. (2016) Cinnamon Extract Exhibits Potent Anti-Proliferative Activity by Modulating Angiogenesis and Cyclooxygenase in Myeloma Cells. Journal of Herbal Medicine, 6, 149-156. https://doi.org/10.1016/j.hermed.2016.04.001

[48] MatÉs, J.M., Pérez-Gómez, C. and De Castro, I.N. (1999) Antioxidant Enzymes and Human Diseases. Clinical Biochemistry, 32, 595-603. https://doi.org/10.1016/S0009-9120(99)00075-2

[49] Dhuley, J.N. (1999) Anti-Oxidant Effects of Cinnamon (Cinnamomum verum) Bark and Greater Cardamom (Amomum subulatum) Seeds in Rats Fed High Fat Diet. Indian Journal of Experimental Biology, 37, 238-242.

[50] Moselhy, S.S. and Ali, H.K. (2009) Hepatoprotective Effect of Cinnamon Extracts against Carbon Tetrachloride Induced Oxidative Stress and Liver Injury in Rats. Biological Research, 42, 93-98. https://doi.org/10.4067/s0716-97602009000100009

[51] Sunkara, R., Shackelford, L., Walker, L. and Verghese, M. (2015) Inhibition of Chemically-Induced Colon Cancer by Dietary Treatment of Hibiscus sabdariffa L. Dried Calyx in Rats. Food and Nutrition Sciences, 6, 1174-1183. https://doi.org/10.4236/fns.2015.612123

[52] Dhuley, J.N. (1999) Anti-Oxidant Effects of Cinnamon (Cinnamomum verum) Bark and Greater Cardamom (Amomum subulatum) Seeds in Rats Fed High Fat Diet. Indian Journal of Experimental Biology, 37, 238-242.

[53] Bhattacharjee, S., Rana, T. and Sengupta, A. (2007) Inhibition of Lipid Peroxidation and Enhancement of GST Activity by Cardamom and Cinnamon during Chemically Induced Colon Carcinogenesis in Swiss Albino Mice. Asian Pacific Journal of Cancer Prevention, 8, 578-582.

[54] Hung, M.Y., Fu, T.Y.C., Shih, P.H., Lee, C.P. and Yen, G.C. (2006) Du-Zhong (Eucommia ulmoides Oliv.) Leaves Inhibits CCl 4-Induced Hepatic Damage in Rats. Food and Chemical Toxicology, 44, 1424-1431.

[55] Liska, D.J. (1998) The Detoxification Enzyme Systems. Alternative Medicine Review, 3, 187-198.

[56] Maliakal, P.P. and Wanwimolruk, S. (2001) Effect of Herbal Teas on Hepatic Drug 
Metabolizing Enzymes in Rats. Journal of Pharmacy and Pharmacology, 53, 13231329. https://doi.org/10.1211/0022357011777819

[57] In, I., Willis, S., Boateng, J., Busambwa, K., Shackelford, L. and Verghese, M. (2016) Hepatoprotective Effects of Bitter Melon and Blueberry Leaf Teas on Endogenous Hepatic Antioxidant Enzymes. Journal of Pharmacology and Toxicology, 11, 1-10.

Submit or recommend next manuscript to SCIRP and we will provide best service for you:

Accepting pre-submission inquiries through Email, Facebook, LinkedIn, Twitter, etc. A wide selection of journals (inclusive of 9 subjects, more than 200 journals)

Providing 24-hour high-quality service

User-friendly online submission system

Fair and swift peer-review system

Efficient typesetting and proofreading procedure

Display of the result of downloads and visits, as well as the number of cited articles Maximum dissemination of your research work

Submit your manuscript at: http://papersubmission.scirp.org/

Or contact fns@scirp.org 